Research Article

\title{
To investigate the role of Memantine as anxiolytic in elevated plus maze test and as antidepressant in tail suspension test in Swiss albino mice
}

\author{
Harish G. Bagewadi*, T. V. Venkatadri, B. Rajeshwari
}

\begin{abstract}
Department of Pharmacology, MVJ Medical College \& Research Hospital, Bengaluru, Karnataka, India

Received: 02 January 2015 Revised: 11 February 2015 Accepted: 17 February 2015

*Correspondence to: Dr. Harish G. Bagewadi, Email: harish2957@gmail. com
\end{abstract}

Copyright: (C) the author(s), publisher and licensee Medip Academy. This is an openaccess article distributed under the terms of the Creative Commons Attribution NonCommercial License, which permits unrestricted noncommercial use, distribution, and reproduction in any medium, provided the original work is properly cited.

\begin{abstract}
Background: The magnitude of improvement seen with present conventional medicines for anxiety and depression remain disappointing thereby providing a scope for the study of newer drugs. In the literature, there is evidence demonstrating the modulation of N-methyl-D-aspartate (NMDA)receptors in anxiety and depression. The present study is undertaken to evaluate the antianxiety effect of memantine in elevated plus maze (EPZ) test and its antidepressant effect in tail suspension test (TST)in Swiss albino mice.

Methods: Animals were divided into six groups $(n=6)$. First group mice were given normal saline $(10 \mathrm{ml} / \mathrm{kg})$, second group were administered lorazepam $(0.5 \mathrm{mg} / \mathrm{kg})$, third group with memantine $(3 \mathrm{mg} / \mathrm{kg})$ and fourth group with memantine plus lorazepam, fifth group was administered amitriptyline $(10 \mathrm{mg} / \mathrm{kg})$ and sixth group received memantine plus amitriptyline. All drugs were administered by intraperitoneal route daily for 7 consecutive days. Results were analyzed by one-way ANOVA followed by post-hoc Tukey's test.

Results: Memantine treated mice showed significant increase $(p<0.001)$ in time spent and number of entries in open arm and significant decrease in time spent and number of entries in closed arm in EPZ when compared to control group. Duration of immobility was significantly $(\mathrm{p}<0.001)$ reduced in animals treated with memantine when compared to the control group in TST.

Conclusions: NMDA antagonist, memantine has showed significant antianxiety effect in EPZ test and antidepressant effect in TST.
\end{abstract}

Keywords: Memantine, N-methyl-D-aspartate-antagonist, Elevated plus maze test, Antianxiety, Tail suspension test, Antidepressant

\section{INTRODUCTION}

The incidence of anxiety disorders in the world is very high and is associated with a lot of morbidities. Prevalence of anxiety in women is $30.5 \%$ and in males is $19.2 \%$ during their lifetime. ${ }^{1}$ Benzodiazepines are the standard anti-anxiety drugs, but they are associated with side effects of sedation and addiction. Buspirone, is a non-sedative anxiolytic agent which causes gastric discomfort, tachycardia, palpitation, as side effects in its long-term usage. ${ }^{2}$

Similarly, depression is one of the major mental disorders. It is common in women, who have a lifetime prevalence of $21.3 \%$ when it is compared to $12.7 \%$ in men. ${ }^{3}$ Most antidepressant medications increase the levels of serotonin and norepinephrine neurotransmitters in the synaptic cleft. Approximately, two-thirds of the patients with depression respond better to the currently available treatments but still the desired magnitude of improvement is not achieved. ${ }^{4}$
Around $5-10 \%$ of patients on selective serotonin reuptake inhibitors discontinue therapy because of side effects related to the gastrointestinal tract and central nervous system as well as weight gain. ${ }^{5}$ Therefore, research for newer antidepressants with greater effectiveness has to be explored.

It has been well-accepted that glutamate deregulation also contributes significantly to anxiety-like disorders. ${ }^{6}$ Among them, N-methyl-D-aspartate (NMDA)receptor is particularly known to play a key role in anxiety disorders. ${ }^{7,8}$ Similarly, over the past decade, interest has turned to a potential role of the glutaminergic system in depression, particularly giving importance to mainly NMDA receptor. ${ }^{7}$ This is a departure from our previous thinking, which had focused on serotonin and norepinephrine. It was reported from an earlier study that the statin dose independently improves depression and anxiety via modulating NMDA receptors. ${ }^{9}$ 
Memantine is a non-competitive NMDA antagonist, which is used in Alzheimer's disease. Previous studies undertaken by us had established the antidepressant ${ }^{10}$ and antianxiety effect of memantine in other experimental models.

In our previous study, we demonstrated antidepressant effect of memantine in other behavioral assessment parameters of depression in animal models like forced swim test and locomotor activity in photoactometer. Memantinetreated mice when compared to the control group revealed significant reduction in the duration of immobility in forced swim test on day "7" when compared to day " 0 ". Although the immobility time in Forced swim test, is also reduced by central nervous system stimulants, but they tend to increase the locomotor activity in the animals. In our previous study it was also found that memantine administered for " 7 " days, did not show any significant change in locomotor activity of mice, as compared to the control group. Which helps to confirm the antidepressant like activity, which is not a false positive finding.

Rationale for using lorazepam in our study as standard antianxiety drug- is to observe for any interaction of memantine (NMDA antagonist)as a test drug with lorazepam as positive control (which also allosterically modulates NMDA receptors), allowing little similarity with standard and test drug action in accordance with NMDA receptor. Lorazepam by interacting with GABA enhances chloride ion conductance and increases the frequency of channel opening events. In addition to this, it was demonstrated from an earlier study that there is interplay of NMDA receptors conditioning and $\mathrm{GABA}_{\mathrm{A}}$ receptors subunits desensitization. In hippocampal neurons, conditioning with $20 \mu \mathrm{M}$ NMDA for $20 \mathrm{sec}$ caused $50 \%$ suppression of GABA responses and lorazepam potentiation reliably increased with $\mathrm{GABA}_{\mathrm{A}}$ receptors when NMDA-induced suppression in plasticity of fast synaptic transmission. ${ }^{11}$ Although either potentiation or suppression can occur, under many conditions $\mathrm{Ca}^{2+}$ influx through NMDA-type glutamate receptors suppresses subsequent responsiveness of $\mathrm{GABA}_{\mathrm{A}}$ receptors. ${ }^{12}$ Lorazepam is having poor lipid solubility and high degree of protein binding (85-90\%), means its volume of distribution is mainly the vascular compartment, causing relatively prolonged peak effects. The plasma levels of lorazepam are proportional to the dose given. There is no evidence of accumulation of lorazepam on administration up to 6 months. The half-life of lorazepam is $10-20 \mathrm{hrs}$.

Rationale for using amitriptyline in our study as standard antidepressant drug - is to observe for any interaction of memantine (NMDA antagonist)as a test drug, with amitriptyline as positive control (which also allosterically modulates NMDA receptors), allowing little similarity with standard and test drug action in accordance with NMDA receptor. Amitriptyline acts primarily as a serotoninnorepinephrine reuptake inhibitor, with strong actions on the serotonin transporter and moderate effects on the norepinephrine transporter. ${ }^{13}$ It has also been shown to be a relatively weak NMDA receptor negative allosteric modulator at the same binding site as phencyclidine. ${ }^{14}$ Recently, amitriptyline has been demonstrated to act as an agonist of the TrkA and TrkB receptors. It promotes the heterodimerization of these proteins and has potent neurotrophic activity both in-vivo and in-vitro in mouse models. ${ }^{14,15}$ These are the same receptors which activate brain-derived nerve growth factor (BDNF), an endogenous neurotrophic with powerful antidepressant effects. In a recent study, it has been indicated that amitriptyline increases reuptake of glutamate through its transporters, resulting in prevention of NMDA-induced excitotoxicity. ${ }^{16,17}$ Amitriptyline is highly bound to plasma and tissue proteins, therefore, have large volumes of distribution $(\sim 20 \mathrm{~L} / \mathrm{kg})$ and its $\mathrm{t}^{1 / 2}$ is $16-24 \mathrm{hrs}$.

The present study was undertaken in order to further strengthen the evidence of memantine as an antianxiety in elevated plus maze (EPZ)test and as an antidepressant drug in tail suspension test (TST)in Swiss albino mice.

\section{METHODS}

\section{Aims and objectives}

To study the antianxiety effect of memantine in EPZ test and to study the antidepressant effect of memantine in TST.

Swiss albino mice of either sex weighing between 25 and $30 \mathrm{~g}$ were obtained from the central animal house of MVJ Medical College and Research Hospital. The animals were housed in cages and kept under controlled environmental condition (temperature $22 \pm 2^{\circ} \mathrm{C}$, humidity $50-55 \%$, natural light/day cycle). All the experiments were performed in the daytime between 09:30 and 15:30 hrs. Care of animals was done according to CPCSEA guidelines. Permission was taken from the Institutional Animal Ethics Committee to carry out the experiment.

\section{Drugs and chemicals}

Memantine (Sun Pharma Drugs Pvt. Ltd. India) and Amitriptyline, Lorazepam (Intas Pharmaceuticals Ltd. India) diluted in normal saline were used.

\section{Experimental design}

The animals were divided into six groups $(n=6)$. Group I - was administered normal saline $(10 \mathrm{ml} / \mathrm{kg}$, intraperitoneal [i.p.])serve as control. Group II - received lorazepam $(0.5 \mathrm{mg} / \mathrm{kg}$, i.p.). Group III - was given the memantine (3 $\mathrm{mg} / \mathrm{kg}$, i.p.).Group IV - was administered memantine (3 mg/kg, i.p.)+ lorazepam (0.5 mg/kg, i.p.). Group V - was treated with amitriptyline $(10 \mathrm{mg} / \mathrm{kg}$, i.p. $)$ and Group VI - received memantine ( $3 \mathrm{mg} / \mathrm{kg}$, i.p. $)+$ 
amitriptyline $(10 \mathrm{mg} / \mathrm{kg}$, i.p.). Memantine, lorazepam, amitriptyline, normal saline were administered by i.p. route daily for 7 days of the experimental period to assess their effects on " 0 " and day " 07 ". The mice were administered drugs and assessment was conducted 30 minutes after drug administration.

\section{Assessment of behavioral tests}

\section{EPZ (Elevated Plus Maze) $)^{18}$}

The elevated plus-maze comprised of two open $(30$ $\mathrm{cm} \times 5 \mathrm{~cm} \times 0.25 \mathrm{~cm})$ and two enclosed $(30 \mathrm{~cm} \times 5 \mathrm{~cm} \times 15 \mathrm{~cm})$ arms that radiated from a central platform $(5 \mathrm{~cm} \times 5 \mathrm{~cm})$ to form a plus sign. The maze is kept elevated $40 \mathrm{~cm}$ above the floor in a dimly-lit room. The test was done by placing an animal on the central platform of the maze facing an open arm. A mouse was considered to have entered an arm, when all four paws were on the arm. As a positive standard, mice were administered lorazepam i.p. During the 5 mins test, preference of the animal for the first entry, the number of entries into the open or closed arm and the time spent in each arm of the maze were noted.

\section{TST (Tail Suspension Test)}

The method is similar to that described by Steru et al. ${ }^{19}$ Mouse was suspended upside down on a metal rod at a height of $55 \mathrm{~cm}$ from the ground with the help of an adhesive tape placed approximately $1 \mathrm{~cm}$ from the tip of the tail. Initially, the mouse tried to escape by making vigorous movements but when unable to escape became immobile. The animal was considered immobile when it did not show any movement of the body and hanged passively. The immobility displayed by rodents when subjected to this kind of unavoidable stress and behavioral despair reflects mental depression in humans. The total duration of immobility is noted during 6 mins period.

\section{Statistical analysis}

Results are presented as mean \pm SEM. One-way ANOVA is used for comparison between the groups, followed by post-hoc Tukey's test. For all the tests, $\mathrm{p} \leq 0.05$ was considered statistically significant.

\section{RESULTS}

In group treated with lorazepam as a standard, animals gave first preference to open arm, there was significant increase $(p<0.001)$ in number of entries and time spent in open arm and significant decrease $(\mathrm{p}<0.001)$ in number of entries and time spent in closed arm $(\mathrm{p}<0.001)$ on day " 0 " and on day " 07 " as compared to control group as shown in Tables 1 and 2.

The mice which received memantine when compared to control group, animals gave first preference to open arm, though there was slight increase in the number of entries and time spent in open arm and slight decrease in the number of entries and time spent in closed arm as compared to control on day " 0 " which was not statistically significant. Whereas, on day " 07 " there was significant increase $(p<0.001)$ in number of entries and time spent in open arm and significant decrease $(p<0.001)$ in number of entries and time spent in closed arm as shown in Tables 1 and 2.

When lorazepam-treated group was compared with memantine received group, animals showed significant increase $(p<0.001)$ in number of entries and time spent in open arm and significant decrease $(p<0.001)$ in number of entries and time spent in closed arm on day " 0 ". But on day " 07 ", there was significant increase $(p<0.01)$ in number of entries in open arm and significant decrease $(p<0.01)$ in number of entries and time spent in closed arm but no statistical significant difference was observed in the time spent by the mice in open arm as shown in Tables 1 and 2 .

On day "0" and day "07", (memantine + lorazepam)treated group, animals showed significant increase $(\mathrm{p}<0.001)$ in number of entries, time spent in open arm and significant decrease $(p<0.001)$ in number of entries, time spent in closed arm when compared to memantine alone treated group as shown in Tables 1 and 2.

When evaluating for the antidepressant effect in TST, the group treated with Amitriptyline as a standard, animals showed significant decrease $(\mathrm{p}<0.001)$ in immobility period on day " 0 " and day " 07 " as compared to control group as shown in Tables 3 and 4. When memantine treated group was compared to the control group, animals showed a slight decrease in the period of immobility on day " 0 " which was not statistically significant. Whereas, on the day "07", a

Table 1: Effect of a single dose observation in EPZ test on day 0.

\begin{tabular}{|lcccc|}
\hline Groups, (dose) & $\begin{array}{c}\text { Number of } \\
\text { entries in O.A }\end{array}$ & $\begin{array}{c}\text { Time spent } \\
\text { in O.A (sec) }\end{array}$ & $\begin{array}{c}\text { Number of } \\
\text { entries in C.A }\end{array}$ & $\begin{array}{c}\text { Time spent } \\
\text { in C.A (sec) }\end{array}$ \\
\hline 1. Normal saline $(10 \mathrm{ml} / \mathrm{kg}$, i.p.) & $2.3 \pm 0.36$ & $23.8 \pm 1.59$ & $16.43 \pm 1.18$ & $265.4 \pm 3.48$ \\
\hline 2. Lorazepam $(0.5 \mathrm{mg} / \mathrm{kg}$, i.p.) & $13.4 \pm 0.77^{*}$ & $201.6 \pm 5.83^{*}$ & $4.7 \pm 0.55^{*}$ & $96.8 \pm 2.24^{*}$ \\
\hline 3. Memantine $(3 \mathrm{mg} / \mathrm{kg}$, i.p.) & $3.1 \pm 1.04^{\dagger \dagger}$ & $31.3 \pm 2.59^{\dagger \dagger}$ & $14.5 \pm 0.61^{\dagger \dagger}$ & $253.2 \pm 2.94^{\dagger \dagger}$ \\
\hline 4. Memantine+lorazepam & $15.8 \pm 1.15^{\dagger+}$ & $245.6 \pm 2.53^{+*}$ & $3.5 \pm 0.31^{+*}$ & $52.5 \pm 2.16^{\dagger+}$ \\
\hline
\end{tabular}

O.A: Open arm, C.A: Closed arm, $n=6$, values expressed as mean \pm SEM. ${ }^{*} \mathrm{p}<0.001$ versus normal saline, ${ }^{\dagger} \mathrm{p}<0.01,{ }^{\dagger} \mathrm{p}<0.001$ versus lorazepam, ${ }^{\dagger} \mathrm{p}<0.01,{ }^{\star \star} \mathrm{p}<0.001$ versus memantine. SEM: Standard error mean, EPZ: Elevated plus maze 
Table 2: Effect of the multiple dose observation in EPZ test on day 7.

\begin{tabular}{|lcccc|}
\hline Groups, (dose) & $\begin{array}{c}\text { Number of } \\
\text { entries in O.A }\end{array}$ & $\begin{array}{c}\text { Time spent in } \\
\text { O.A (sec) }\end{array}$ & $\begin{array}{c}\text { Number of } \\
\text { entries in C.A }\end{array}$ & $\begin{array}{c}\text { Time spent in } \\
\text { C.A (sec) }\end{array}$ \\
\hline 1. Normal saline $(10 \mathrm{ml} / \mathrm{kg}$, i.p.) & $3.2 \pm 0.34$ & $21.9 \pm 0.89$ & $13.8 \pm 1.49$ & $269.7 \pm 14.43$ \\
\hline 2. Lorazepam $(0.5 \mathrm{mg} / \mathrm{kg}$, i.p.) & $15.3 \pm 1.29^{*}$ & $210.4 \pm 6.94^{*}$ & $3.2 \pm 0.41^{*}$ & $82.7 \pm 1.85^{*}$ \\
\hline 3. Memantine $(3 \mathrm{mg} / \mathrm{kg}$, i.p.) & $10.8 \pm 1.18^{*, \dagger}$ & $194.9 \pm 4.08^{*}$ & $7.7 \pm 0.65^{* \dagger}$ & $123.1 \pm 1.91^{*, \dagger}$ \\
\hline 4. Memantine+lorazepam & $17.5 \pm 0.82^{+\dagger}$ & $260.8 \pm 5.01^{\text {t+ }}$ & $2.8 \pm 0.43^{\text {+⿱ }}$ & $37.2 \pm 1.18^{+*}$ \\
\hline
\end{tabular}

O.A: Open arm, C.A: Closed arm, $\mathrm{n}=6$, values expressed as mean \pm SEM. ${ }^{*} \mathrm{p}<0.001$ versus normal saline, ${ }^{\dagger} \mathrm{p}<0.01$, ${ }^{\dagger} \mathrm{p}<0.001$ versus lorazepam, ${ }^{\star} \mathrm{p}<0.01,{ }^{*} \mathrm{p}<0.001$ versus memantine. SEM: Standard error mean, EPZ: Elevated plus maze

Table 3: Effect of a single dose observation in TST on day 0.

\begin{tabular}{|lc|}
\hline Groups, (dose) & $\begin{array}{c}\text { Duration of } \\
\text { immobility (sec) }\end{array}$ \\
\hline 1. Control $(10 \mathrm{ml} / \mathrm{kg}$, i.p.) & $175.8 \pm 2.63$ \\
\hline 3. Memantine $(3 \mathrm{mg} / \mathrm{kg}$, i.p.) & $167.5 \pm 3.56^{\dagger}$ \\
\hline 5. Amitriptyline $(10 \mathrm{mg} / \mathrm{kg}$, i.p.) & $107.2 \pm 2.87^{*}$ \\
\hline 6. Memantine+Amitriptyline & $86.3 \pm 1.54^{\star *}$ \\
\hline
\end{tabular}

$\mathrm{n}=6$, values expressed as mean \pm SEM. $* \mathrm{p}<0.001$ versus normal saline-control, ${ }^{\dagger} \mathrm{p}<0.01$ versus Amitriptyline, ${ }^{\star} \mathrm{p}<0.01,{ }^{\star \star} \mathrm{p}<0.001$ versus memantine. SEM: Standard error mean, TST: Tail suspension test

significant decrease $(\mathrm{p}<0.001)$ in immobility period was noticed as shown in Tables 3 and 4.

In group treated with amitriptyline, animals showed significant decrease $(p<0.01)$ in immobility period on day " 0 ". But on day " 07 ", there was no statistically significant difference in the immobility period when compared to memantine treated group as shown in Tables 3 and 4. When (memantine + amitriptyline)-treated group was compared with the group which received memantine alone a statistically significant decrease in immobility period was seen on day " 0 " ( $(p<0.001)$ as well as on day "07”, $(\mathrm{p}<0.01)$ as shown in Tables 3 and 4.

\section{DISCUSSION}

The etiology of most anxiety disorders is not fully understood, but various studies have shown the involvement of GABAergic and serotonergic neurotransmission in its etiology. ${ }^{20,21}$ The EPZ is commonly used to assess anxiety related behavior. In the EPZ, avoidance of the open arms, increase in time spent in the closed arms, and a decrease in rearing indicates anxiety. ${ }^{22}$ Study by Poleszak et al. ${ }^{23}$ shows that NMDA receptor activation antagonizes the NMDA antagonist-induced antianxiety effect in the elevated plusmaze test in mice. Over the past decade, interest has turned to a potential role of the glutaminergic system in depression particularly with focus on NMDA receptor. ${ }^{4}$ This encouraged us to study the effect of NMDA antagonist, memantine in experimental models of anxiety and depression.

In our study, memantine produced significant anxiolytic effect when compared to the normal saline, as well as the

\section{Table 4: Effect of the multiple dose observation in} TST on day 7.

\begin{tabular}{|lc|}
\hline Groups, (dose) & $\begin{array}{c}\text { Duration of } \\
\text { immobility (sec) }\end{array}$ \\
\hline 1. Control (10 ml/kg, i.p.) & $179.6 \pm 2.39$ \\
\hline 3. Memantine $(3 \mathrm{mg} / \mathrm{kg}$, i.p.) & $93.3 \pm 1.54^{*}$ \\
\hline 5. Amitriptyline $(10 \mathrm{mg} / \mathrm{kg}$, i.p.) & $84.5 \pm 1.71^{*}$ \\
\hline 6. Memantine+Amitriptyline & $78.1 \pm 3.96^{\star}$ \\
\hline
\end{tabular}

$\mathrm{n}=6$, values expressed as mean \pm SEM. * $\mathrm{p}<0.001$ versus normal saline-control, ${ }^{\dagger} \mathrm{p}<0.01$ versus Amitriptyline, ${ }^{\star} \mathrm{p}<0.01,{ }^{*} \mathrm{p}<0.001$ versus memantine. SEM: Standard error mean, TST: Tail suspension test

standard lorazepam-treated group. A synergistic interaction between memantine and lorazepam was also observed in their antianxiety effect. Similar antianxiety effects were demonstrated from previous studies depicting antianxiety effect of other competitive NMDA receptor antagonists. ${ }^{22,23}$

When the antidepressant activity of memantine was studied in TST, it showed a significant decrease in the duration of immobility when compared to amitriptyline treated group. Mice treated with memantine when compared to the normal saline-treated group, memantine significantly reduced the immobility in TST, on the day "7" when compared to day "0". A synergistic interaction between memantine and amitriptyline was observed in the antidepressant effect. The above finding of antidepressant activity of memantine was similar to a previous study by Karve et al. ${ }^{24}$ Similarly, other previous studies by Patel et al. ${ }^{25}$ and Poleszak et al. ${ }^{26}$ have demonstrated antianxiety and antidepressant effects as well.

There is improved clinical tolerability of memantine in comparison to other NMDA antagonists which have shown antianxiety effects like phencyclidine. ${ }^{27-30}$ The preclinical and clinical data provide strong evidences that diverse antagonists and partial agonists, acting at different sites of NMDA receptor complex exhibit anxiolytic-like activity. Quite often, they have been compared to benzodiazepines or barbiturates. ${ }^{8,31,32}$

The hypothesis by Olney et al. ${ }^{33}$ suggest that over-activation of NMDA receptors leads to damage of GABA neurons and secondary damage produced by disinhibited neurons (e.g. glutamate, Ach, neuropeptide Y [NPY]). A new 
study in mice by Zarate et al. shows that blocking the NMDA receptor increases the activity of another receptor, $\alpha$-amino-3-hydroxy-5-methyl-4-isoxazole propionic acid (AMPA)and this boost in AMPA activity is crucial for rapid antidepressant actions. It has been reported that activation of AMPA glutamate receptors increases BDNF expression and stimulates neurogenesis and neuronal sprouting, in the hippocampus. ${ }^{34}$ The infusion of NMDA into either the raphe nuclei or frontal cortex has revealed to alter local 5-HT release and also serotonergic transmission. ${ }^{35}$

The previous study by Wieronska et al..$^{36}$ indicates that in the amygdala, the NMDA receptors mediated glutaminergic transmission may regulate NPY neurons. There is also evidence showing topiramate (NMDA receptor modulator) altering the NPY activity in flinders sensitive line "depressed" rats. ${ }^{37}$ Activity of memantine on NPY activity, which might contribute to the antidepressant and antianxiety activity, cannot be ruled out providing a new way for its further exploration.

\section{CONCLUSION}

Memantine has demonstrated antianxiety effect which was comparable to lorazepam. Memantine could be producing its antianxiety activity by blocking NMDA receptor. There was the synergism in antianxiety activity of memantine and lorazepam. Memantine has also found to exert antidepressant activity which was comparable to Amitriptyline by blocking NMDA receptor. However, it's modulating effect on NPY which might contribute to antianxiety, and antidepressant activity has to be further explored.

\section{Funding: No funding sources}

Conflict of interest: None declared

Ethical approval: The study was approved by the Institutional Ethics Committee

\section{REFERENCES}

1. Kessler RC, McGonagle KA, Zhao S, Nelson CB, Hughes M, Eshleman $\mathrm{S}$, et al. Lifetime and 12-month prevalence of DSM-III-R psychiatric disorders in the United States. Results from the National Comorbidity Survey. Arch Gen Psychiatry. 1994;51(1):8-19.

2. Tevor AJ, Way WL. Sedative and the hynotics drugs. In: Katzung BG, editors. Basic and Clinical Pharmacology. $11^{\text {th }}$ Edition. San Francisco: The McGraw Hill Companies; 2009: 406-7.

3. Kessler RC, McGonagle KA, Swartz M, Blazer DG, Nelson CB. Sex and depression in the National Comorbidity Survey. I: lifetime prevalence, chronicity and recurrence. J Affect Disord. 1993;29(2-3):85-96.

4. Kessler RC, Berglund P, Demler O, Jin R, Merikangas KR, Walters EE. Lifetime prevalence and age-of-onset distributions of DSM-IV disorders in the National Comorbidity Survey Replication. Arch Gen Psychiatry. 2005;62(6):593-602.

5. Koenig AM, Thase ME. First-line pharmacotherapies for depression - What is the best choice? Pol Arch Med Wewn. 2009;119(7-8):478-86.

6. Simon $\mathrm{AB}$, Gorman JM. Advances in the treatment of anxiety: targeting glutamate. NeuroRx. 2006;3(1):57-68.

7. Trullas R, Skolnick P. Functional antagonists at the NMDA receptor complex exhibit antidepressant actions. Eur J Pharmacol. 1990;185(1):1-10.

8. Jessa M, Nazar M, Bidzinski A, Plaznik A. The effects of repeated administration of diazepam, MK- 801 and CGP 37849 on rat behavior in two models of anxiety. Eur Neuropsychopharmacol. 1996;6(1):55-61.

9. Young-Xu Y, Chan KA, Liao JK, Ravid S, Blatt CM. Longterm statin use and psychological well-being. J Am Coll Cardiol. 2003;42(4):690-7.

10. Bagewadi HG, Nayaka SR, Venkatadri TV. Effect of memantine in experimental models of depression in swiss albino mice. J Chem Pharm Res. 2014;6(12):885-91.

11. Chisari M, Zorumski CF, Mennerick S. Cross talk between synaptic receptors mediates NMDA-induced suppression of inhibition. J Neurophysiol. 2012;107(9):2532-40.

12. Stelzer A, Shi H. Impairment of GABA-A receptor function by N-methyl-D-aspartate-mediated calcium influx in isolated CA1 pyramidal cells. Neuroscience. 1994;62(3):813-28.

13. Tatsumi M, Groshan K, Blakely RD, Richelson E. Pharmacological profile of antidepressants and related compounds at human monoamine transporters. Eur J Pharmacol. 1997;340(2-3):249-58.

14. Sills MA, Loo PS. Tricyclic antidepressants and dextromethorphan bind with higher affinity to the phencyclidine receptor in the absence of magnesium and L-glutamate. Mol Pharmacol. 1989;36(1):160-5.

15. Jang SW, Liu X, Chan CB, Weinshenker D, Hall RA, Xiao G, et al. Amitriptyline is a TrkA and TrkB receptor agonist that promotes TrkA/TrkB heterodimerization and has potent neurotrophic activity. Chem Biol. 2009;16(6):644-56.

16. Mao QX, Yang TD. Amitriptyline upregulates EAAT1 and EAAT2 in neuropathic pain rats. Brain Res Bull. 2010;81(45):424-7.

17. Sernagor E, Kuhn D, Vyklicky L Jr, Mayer ML. Open channel block of NMDA receptor responses evoked by tricyclic antidepressants. Neuron. 1989;2(3):1221-7.

18. Pellow S, Chopin P, File SE, Briley M. Validation of open: closed arm entries in an elevated plus-maze as a measure of anxiety in the rat. J Neurosci Methods. 1985;14(3):149-67.

19. Steru L, Chermat R, Thierry B, Simon P. The tail suspension test: a new method for screening antidepressants in mice. Psychopharmacology (Berl).1985;85(3):367-70.

20. Graeff FG, Guimaraes FS, De Andrade TG, Deakin JF. Role of 5-HT in stress, anxiety, and depression. Pharmacol Biochem Behav. 1996;54(1):129-41.

21. Griebel G. 5-hydroxytryptamine pathways in anxiety and its treatment. Pharmacol Ther. 1995;66:103-48.

22. Fernandez Espejo E. Structure of the mouse behaviour on the elevated plus-maze test of anxiety. Behav Brain Res. 1997;86(1):105-12.

23. Poleszak E, Serefko A, Szopa A, Wosko S, Dudka J, Wrobel A, et al. NMDA receptor activation antagonizes the NMDA antagonist-induced antianxiety effect in the elevated plus-maze test in mice. Pharmacol Rep. 2013;65(5):1124-31.

24. Karve AV, Jagtiani SS, Chitnis KA. Evaluation of effect of allopurinol and febuxostat in behavioral model of depression in mice. Indian J Pharmacol. 2013;45(3):244-7.

25. Patel P, Gohil KJ, Roy SP, Patel N. Investigation of antidepressant and anxiolytic activity of curcumin given 
alone and in combination with amitriptyline in rats. Indian J Res Pharm Biotechnol. 2014;2(3):1173-8.

26. Poleszak E, Szewczyk B, Kedzierska E, Wlaz P, Pilc A, Nowak G. Antidepressant and anxiolytic-like activity of magnesium in mice. Pharmacol Biochem Behav. 2004;78(1):7-12.

27. Graeff FG, Guimaraes FS, De Andrade TG, Deakin JF. Role of 5-HT in stress, anxiety, and depression. Pharmacol Biochem Behav. 1996;54(1):129-42.

28. Lipton SA. Failures and successes of NMDA receptor antagonists: molecular basis for the use of open-channel blockers like memantine in the treatment of acute and chronic neurologic insults. NeuroRx. 2004;1(1):101-10.

29. Lipton SA. The molecular basis of memantine action in Alzheimer's disease and other neurologic disorders: lowaffinity, uncompetitive antagonism. Curr Alzheimer Res. 2005;2(2):155-65.

30. Lipton SA, Chen HS. Paradigm shift in neuroprotective drug development: clinically tolerated NMDA receptor inhibition by memantine. Cell Death Differ. 2004;11(1):18-20.

31. Kotlinska J, Liljequist S. A characterization of anxiolytic-like actions induced by the novel NMDA/glycine site antagonist, L-701,324. Psychopharmacology (Berl). 1998;135(2):175-81.

32. Przegalinski E, Tatarczynska E, Chojnacka-Wójcik E. The influence of the benzodiazepine receptor antagonist flumazenil on the anxiolytic-like effects of CGP 37849 and ACPC in rats. Neuropharmacology. 2000;39(10):1858-64.

33. Olney JW, Wozniak DF, Farber NB. Glumate receptor dysfunction and Alzheimer's disease. Restor Neurol Neurosci. 1998;13(1-2):75-83.

34. Duman RS. Role of neurotrophic factors in the etiology and treatment of mood disorders. Neuromolecular Med. 2004;5(1):11-25.

35. Lejeune F, Gobert A, Rivet JM, Millan MJ. Blockade of transmission at NMDA receptors facilitates the electrical and synthetic activity of ascending serotoninergic neurones. Brain Res. 1994;656(2):427-31.

36. Wieronska JM, Branski P, Palvcha A, Smialowska M. The effect of competitive and non-competitive NMDA receptor antagonists, ACPC and MK-801 on NPY and CRF-like immunoreactivity in the rat brain amygdala. Neuropeptides. 2001;35(5-6):219-26.

37. Husum H, Van Kammen D, Termeer E, Bolwig G, Mathe A. Topiramate normalizes hippocampal NPY-LI in flinders sensitive line 'depressed' rats and upregulates NPY, galanin, and CRH-LI in the hypothalamus: implications for mood-stabilizing and weight loss-inducing effects. Neuropsychopharmacology. 2003;28(7):1292-9.

doi: $10.5455 / 2319-2003$. ijbcp20150403

Cite this article as: Bagewadi HG, Venkatadri TV,

Rajeshwari B. To investigate the role of memantine as anxiolytic in elevated plus maze test and as antidepressant in tail suspension test in Swiss albino mice. Int J Basic Clin Pharmacol 2015;4:213-8. 